\title{
Revolução, contrarrevolução e homossexualidade em Cuba: alguns apontamentos
}

\author{
Jorge Luiz Teixeira Ribas ${ }^{1}$
}

\begin{abstract}
RESUMO
Este artigo discute o conceito de "contrarrevolução" na historiografia da Revolução Cubana, inserindo nesse campo de discussão a eliminação da homossexualidade como objetivo político dos revolucionários, sendo os homossexuais considerados pelo regime como contrarrevolucionários por excelência. A ideia de contrarrevolução é ainda muito restrita a oposições políticas contrárias à revolução (imperialismo, luta armada e organizações políticas) negligenciando indivíduos que, malgrado não atuarem deliberadamente contra o regime, foram combatidos como contrarrevolucionários com base em critérios morais e sexuais. A desconsideração dos homossexuais como contrarrevolucionários na historiografia deve-se ao próprio silêncio existente na historiografia em relação à perseguição homofóbica promovida pelo regime de Fidel Castro. Dessa forma, serão abordados os critérios e atividades que têm definido o campo dos opositores ao regime revolucionário na historiografia, apontando para as limitações e possibilidades do termo, propondo o alargamento do debate e aprofundando a compreensão do fenômeno, com base no delineamento da homossexualidade como lócus contrarrevolucionário por parte da ideologia revolucionária instaurada em 1959 em Cuba.
\end{abstract}

Palavras-chave: Historiografia. Contrarrevolução. Homossexualidade.

\begin{abstract}
This article discusses the concept of "counterrevolution" in the history of the Cuban Revolution, eliminating on this discussion field the subject of homosexuality as a political objective of the revolutionaries, and homosexuals considered by the regime as counterrevolutionaries by excellence. The idea of counterrevolution is still very restricted to the political opposition against the revolution (imperialism, armed struggle, and political organizations) neglecting individuals who, instead of acting deliberately against the regime, were opposed as counterrevolutionaries on the basis of moral and sexual criteria. The disregard of homosexuals as counterrevolutionaries in historiography is caused by the historiography silence regarding the homophobic persecution promoted by the regime of Fidel Castro. This way, this article will approach the activities and practices defined by the field of the opponents of the revolutionary regime in historiography, pointing to the limitations and possibilities of the term, proposing the enlargement of the debate and deepening the understanding of the phenomenon, based on the delineation of homosexuality as a
\end{abstract}

\footnotetext{
${ }^{1}$ Mestre em História Social pela Universidade Estadual de Montes Claros. Orientado pela Profa. Dra. Ivete Batista da Silva Almeida. É pesquisador do Grupo de Pesquisa em História e Cultura Visual UFU/CNPq e membro do Grupo de Pesquisa Gênero e Violência/GEVI/UNIMONTES/CNPq.
} 
counterrevolutionary locus by the revolutionary ideology established in 1959 in Cuba.

Keywords: Historiography. Counter-revolution. Homosexuality.

\section{Introdução}

No ano de 2019 será comemorado o aniversário de 60 anos da Revolução Cubana. Até aqui, muita coisa se disse sobre a revolução, e muita coisa ainda está por ser dita ou revisada. Entre os inúmeros aspectos que podem ser (re)explorados sobre o processo revolucionário cubano às vésperas de seus 60 anos, a saber, política, comunismo, ideologia, cultura, sociedade, economia, autoritarismo, imaginário, geopolítica, gênero, etc., neste artigo será feito uma breve discussão sobre o tema da contrarrevolução, apontando para a face sombria do regime cubano que perseguiu sistematicamente minorias sexuais na ilha no âmbito de suas medidas políticas de consolidação revolucionária. Durante essas seis décadas, muito pouco se falou sobre este assunto específico, quando a historiografia tem se dedicado muito mais às questões políticas, econômicas e ideológicas para a compreensão do processo revolucionário quando persistiu uma concepção política de Estado baseado em preceitos morais dentro dos quais a nova sociedade criada pelos revolucionários só vigoraria com a erradicação completa da homossexualidade do seio social, perpetrando, assim uma série de violências contra milhares de indivíduos que não se adequaram ao perfil oficial de "ser revolucionário" do regime. Essa carência persiste ainda hoje nas discussões gerais sobre a revolução, como se fosse algo meramente insignificante para ser abordado, e reflete na própria compreensão e no ensino sobre a revolução.

Dito de outra forma, no combate às oposições políticas durante a consolidação revolucionária, os homossexuais foram considerados contrarrevolucionários por excelência e uma ameaça à integridade nacional. No entanto, a concepção de contrarrevolução na historiografia ainda é hegemonicamente pautada nos critérios de oposição política e ideológica 
explícita ao regime, baseada em ações conscientes de crítica, atos políticos conflagrados em ataques, sabotagens ou exílios com base em interesses contrários ao regime e aos avanços sociais da revolução. Assim, propomos problematizar a categoria da "contrarrevolução", inserindo os indivíduos que, em vez de tomarem determinadas posições políticas que divergiam da dirigência revolucionária e que por isso foram perseguidos, viram-se considerados contrarrevolucionários pelo aparato político-ideológico por questões morais e sexuais. Com isso, enseja-se que as medidas de perseguição às minorias sexuais em Cuba nas primeiras décadas revolucionárias emerjam nas análises sobre a revolução para romper com o manto de silêncio que apaga esses indivíduos da história e que impede, assim, uma compreensão mais completa dos significados do processo revolucionário.

\section{Historiografia da contrarrevolução}

Em texto recente, Calegari (2016) fez um balanço sobre como a historiografia tem tratado o fenômeno da contrarrevolução em Cuba. Pela própria carência de trabalhos sobre a questão, tal balanço foi feito com base sobretudo em autores cubanos, uma vez que fora da ilha o assunto praticamente não é explorado, devido à verdadeira ausência de documentos e textos sobre o tema fora de Cuba.

Segundo a autora, o tema da contrarrevolução é extremamente recente no cenário historiográfico, despontando-se apenas na segunda metade da década de 1990, já no final do século XX, com a crítica do historiador cubano Joel James Figorola (1995), que lamentou a hegemonia de uma historiografia que majoritariamente exaltava as conquistas da revolução e as guerras de independência cubana do século XIX (temas sobretudo de história política tradicional) em detrimento de outras temáticas. Mas a mudança efetiva desse quadro viria nos anos 2000, com os cubanos Jesus Arboyela Cervera (2000) e Fabián Escalante Font (2008). 
Ainda assim, escreve Calegari, esses autores não demonstraram a complexidade heterogênea do que eles tomaram por oposição ao regime de Fidel Castro, nem contestaram os cânones oficiais que nortearam a historiografia cubana desde 1959: a ideia de revolução, pátria, socialismo como entidades máximas e unânimes, em sintonia com a ortodoxia ideológica dos dirigentes. Calegari (2016, p. 141) aponta que "tanto a problematização das motivações políticas para a dissidência, quanto os enfrentamentos ocorridos no campo das ideias e da estruturação do governo não são tratados nas obras dos autores cubanos”. Além disso, Calegari informa em suas conclusões uma questão importante sobre a noção de contrarrevolução nesses autores: Tanto Cervera quanto Font concebem a contrarrevolução no quadro restrito das ações de organizações armadas contra o regime, articuladas com os Estados Unidos, seu aparato de espionagem (CIA) e poder bélico (Pentágono) que respondiam basicamente a duas coisas: 1) ao desejo dos EUA de acabar com o processo revolucionário através de grupos armados; 2) a vingança das classes sociais dominantes abastadas e despossuídas após 1959 (burguesia exilada) pelas leis revolucionárias de justiça social (CALEGARI, 2016, p. 135-136). Ambos historiadores colocam em segundo plano os debates e disputas por hegemonia no interior do processo revolucionário que empobrecem a compreensão da complexidade das posturas políticas em qualquer contexto, as motivações circunstanciais, situando o regime revolucionário sempre na condição de defensiva diante de ataques imperialistas e burgueses internos e externos. ${ }^{2}$

\footnotetext{
2 Em cuba, há uma especificidade sobre a produção historiográfica nacional que diz respeito ao fato de que os institutos de pesquisa são fortemente angariados pelos investimentos estatais que, se de um lado fomenta a pesquisa no país, de outro, acaba por reforçar a manutenção de uma linha oficial na escrita da história. Cervera e Font, além de serem acadêmicos, ambos participaram diretamente do processo revolucionário e foram funcionários do regime cubano. CALEGARI, Ana Paula Cecon. Balanço sobre a historiografia para o estudo da "contrarrevolução cubana". Revista Eletrônica da ANPHLAC, n. 21, p. 125-148, Jul./Dez., 2016. p. 125-148.
} 
Tal concepção da contrarrevolução consolidou-se como um modelo interpretativo da história da Revolução Cubana. Os historiadores que adiante trataram o tema não variaram muito a disposição dos elementos explicativos para o fenômeno, situando a contrarrevolução como um grupo homogêneo, à serviço do imperialismo, que perpetrava ataques à Cuba e à revolução de maneira a desbancar o regime revolucionário, que por seu lado, como reposta às ameaças, radicalizou-se e recrudesceu as medidas políticas de defesa nacional, com a perseguição implacável aos contrarrevolucionários e militarização da ilha. Assim, Calegari demonstra com base em publicações recentes que os autores cubanos não consideram que grande parte dos opositores políticos (armados ou não) em relação aos rumos revolucionários, não necessariamente estavam afinados com os interesses do Pentágono, além do que, as motivações políticas para a dissidência e os embates no campo das ideias não são tratados por esses autores (CALEGARI, 2016, p. 140-141).

Uma visão mais crítica viria de historiadores de fora da ilha, como Keit Bolender (2011), do Canadá, para quem a instabilidade interna e externa da ilha no contexto de Guerra Fria, com as diversas ameaças (reais ou imaginárias) à revolução, levou a uma "hipersensibilidade" às críticas que enxergava as visões não totalmente atinadas ao regime em voga como sinal de oposição, mas que, no entanto, havia uma variedade de percepções. Nessa linha, Claudia Hilb (2010), pesquisadora argentina, destacou que a centralização política do regime motivou diversas dissidências no plano político, cultural, ideológico etc., de maneira a romper com a pretensão de homogeneidade em tal campo (CALEGARI, 2016, p. 136; 141).

A brasileira Silvia Cezar Miskulin (2002; 2009; 2013), embora evite termos como "oposição" ou "contrarrevolução", desenvolveu pesquisas relacionadas à participação dos intelectuais na revolução. A historiadora demonstrou que houve uma participação intensa dos artistas e intelectuais no processo revolucionário desde seu início, configurando-se um grupo heterogêneo, combatente e difuso, com diversos posicionamentos em relação 
aos acontecimentos políticos e culturais, que foram expressados em debates e publicações em suplementos literários, como Lunes de Revolución, El Caimán Barbudo e pela direção da editora El puente. Com base nos trabalhos de Miskulin, até o final da década de 1960 existiu em Cuba um debate plural de ideias, mas que, na medida em que se aproximava a década de 1970, o recrudescimento político do regime, enrijecido na ortodoxia ideológica de vertente comunista, cerceou a liberdade de expressão em Cuba e muitos intelectuais tiveram conflitos com a ideologia oficial em função de suas ideias. Diversos intelectuais foram afastados de seus postos, e o suplemento literário Lunes, por exemplo, foi fechado em 1961, pouco depois de Fidel Castro proferir seu famoso discurso "Palavras aos intelectuais", do qual resultou uma frase enigmática: "Pela Revolução, tudo. Contra a Revolução, nada!", sendo incisivo a respeito das possibilidades de autonomia crítica no cenário cultural da ilha, dando o tom que se seguiria pelos próximos anos em todas as áreas de atuação política, quando muitos caíram na margem escura do submundo da contrarrevolução por não se adequarem à ideologia oficial do regime.

Com essas perspectivas do ponto de vista da participação dos intelectuais, o exílio, a censura literária, ampliou-se o leque de possibilidades para se pensar o fenômeno da contrarrevolução, bem como sua complexidade, que deve levar em conta, portanto, diversos fatores que abrangem uma zona cinzenta de posturas e formas de atuação numa dada circunstância política, que diz respeito a diversos sujeitos, e que dessacralizam a noção reificada de revolução como sinônimo de consenso inabalável entre os cubanos.

A noção binária revolucionário-contrarrevolucionário jamais explicaria a complexidade e a diversidade das formas de adesão ou oposição política que variam de acordo cada momento, nem dá conta dos outros projetos políticos que foram apresentados no processo de construção da sociedade revolucionária mas que foram sobrepujados na disputa interna do poder. O que significa dizer que, numa determinada situação, alguém que 
não era considerado um contrarrevolucionário, passa a ser como tal em relação à posição dos dirigentes na política oficial do regime, como foi o caso de diversos intelectuais. Além dos opositores declarados, muitos dos quais saíram de Cuba ainda na aurora revolucionária, articulando a volta à ilha com o auxílio da CIA, através do ataque à Playa Girón, na Baía dos Porcos em 1961, com o objetivo de controlar parte do território da ilha e derrotar o regime de Fidel, ainda não foram esclarecidas as motivações de muitas outras formas de crítica e oposição ao regime, desde os guerrilheiros da Serra de Escambray, que resistiram até 1965 entre a selva, aos diversos presos políticos, intelectuais exilados ou não, censurados ou destituídos de seus empregos. Nem se deu a devida atenção aos sujeitos considerados como contrarrevolucionários unilateralmente pelo regime, que procurou construir legitimidade com base na perseguição dos desafetos ideológicos internos.

Assim, o tema da contrarrevolução, apesar de alguns avanços, possui limitações evidentes. A narrativa sobre esses grupos permanecem, apesar de alguns avanços, na perspectiva oficial de alinhar as expectativas gerais em relação à revolução com a direção comunista que se tornou hegemônica com a criação do Partido Comunista em 1965, apagando outros projetos, outros possíveis, silenciando-os como contrarrevolucionários sob a justificativa da urgência de se defender a revolução aos ataques estrangeiros quando, muitas vezes, tratavam-se de críticas construtivas para a sociedade que se estruturava. Se por um lado corre-se o risco de reduzir a contrarrevolução às ações armadas articuladas aos interesses dos EUA, como o fazem os historiadores cubanos alinhados à perspectiva política oficial do regime, criando-se a aparência de que não houveram disputas sobre os significados da revolução, sendo o consenso em torno de Fidel algo absoluto, por outro, esta noção diminui a importância dos diversos críticos, como muitos intelectuais apontados nos trabalhos de Miskulin, que se articularam e expressaram suas ideias o quanto puderam, apresentando propostas essencialmente diferentes ao rumo que tomou o regime revolucionário, principalmente no campo da cultura, mas que acabaram enquadrados pelo 
autoritarismo centralizado na ortodoxia ideológica no final da década de 1960.

Em direção ao nosso objeto sobre não se levar em conta, na concepção do fenômeno contrarrevolucionário, os indivíduos que foram assim considerados com base em critérios morais e sexuais, o mérito dos trabalhos de Miskulin é que, ao analisar a participação e os conflitos enfrentados pelos intelectuais no interior da revolução, seja de alinhamento ou divergência ideológica, a autora aponta para o fato de que a homossexualidade era um detalhe agravante a qualquer indivíduo em Cuba, como demonstrou com o caso de José Mario Rodriguez, diretor da editora El Puente, afastado do cargo por ser homossexual (MISKULIN, 2009). A autora insistirá mais na questão da homossexualidade e suas implicações relacionadas à revolução posto que aquele que a praticasse era passível de prisão e submissão ao trabalho forçado - num artigo mais recente, de 2013, em que abordou o caso escritor e dramaturgo homossexual cubano Virgílio Piñera. ${ }^{3}$ Nesse texto é demonstrado, como base em diversos acontecimentos políticos e resoluções governamentais, que o fato de alguém ser homossexual, automaticamente o tornava um contrarrevolucionário. O homossexual era, por assim dizer, incondizente com a própria ideia de revolução. A revolução, para vigorar-se haveria de, inevitavelmente, erradicar a existência da homossexualidade em Cuba, por se considerar que se tratava de um vício burguês, pertencente às depravações morais do passado pré-revolucionário, componente maligno das relações sociais resultante de séculos de exploração colonial e que foram superados pela revolução. O que sustentou o trabalho de Miskulin sobre o caso de Virgílio Piñera foi um cruzamento de fontes não oficiais, como a autobiografia do intelectual com outras memórias de outros escritores exilados que se dispuseram a relatar aspectos de sua subjetividade que dizem respeito à sexualidade e os conflitos enfrentados em sua decorrência.

\footnotetext{
${ }^{3}$ MISKULIN, Sílvia Cezar. História, literatura e homossexualidade em Cuba: o caso de Virgílio Piñera. In.: COSTA, Adriane Vidal; BARBO, Daniel (orgs.). História, Literatura e Homossexualidade. Belo Horizonte: Fino Traço, 2013. p. 129-153.
} 
Sobre o tema da homossexualidade na revolução, aliás, as principais fontes tem sido as publicações feitas por escritores no exílio, apesar de não ter sido esse o caso de Virgílio Piñera, que morreu em Cuba, completamente silenciado e esquecido, mas é o caso, por exemplo, de Reinaldo Arenas e Lezama Lima.

Além de fontes autobiográficas, literárias e uma bibliografia sobre os intelectuais e a revolução, a autora utilizou de referências esparsas que trata de alguma maneira sobre o assunto da homossexualidade. Vale ressaltar o livro do estadunidense Allen Young (1984), um dos pioneiros no estudo dos homossexuais sob a revolução, intitulado Los gays bajo la Revolución Cubana, e algumas fontes disponíveis no Brasil, em especial a cronologia bastante completa da revolução feita por Teresa Cristófani Barreto (1996), em seu trabalho que analisa a obra de Virgílio Piñera, e que informa uma série de investidas por parte do regime contra os homossexuais, desde rondas noturnas a leis de segregação. Antes mesmo do trabalho de Barreto, foi publicado no Brasil em 1980, pelo Editorial Livramento, as Resoluções do $1^{\circ}$ Congresso nacional de Educação e Cultura, que aconteceu em Cuba em abril de 1971, no qual foi definida a política cultural cubana através do controle dos comportamentos considerados desviantes, cujo alvo privilegiado foram os homossexuais, submetendo-lhes ao isolamento, ao silêncio e à humilhação. Pode-se citar também os relatos de Carlos Franqui (1981), em seu Retrato de Família com Fidel.

Embora Miskulin não esteja interessada no assunto da contrarrevolução em si, com a abordagem sobre Piñera, deu-se um passo importante para enfrentar o silêncio existente na historiografia da revolução a respeito da perseguição aos homossexuais na historiografia brasileira. Além disso, contribui para renovar a historiografia da revolução com base em abordagens que chamam a atenção para a experiência de sujeitos historicamente excluídos das histórias nacionais, trazendo a tona questões prementes sobre a constituição das sociedades modernas levando em conta problemas de gênero e sexualidade que, sem eles, a compreensão das 
experiências humanas permanecem bastante limitadas, assim como impede um aprofundamento sobre os significados do processo revolucionário mantendo de fora das discussões medidas do Estado das mais importantes.

A inserção dos homossexuais na historiografia da revolução acrescenta, assim, à noção de contrarrevolução, aqueles sujeitos que foram, de maneira imprecavida mas implacável, considerados contrarrevolucionários pelo regime que estruturou uma perseguição sistemática, justificada ideologicamente, traduzida em medidas políticas que irromperam no cenário político nacional mas que, no entanto, foram completamente esquecidos das discussões sobre o tema, por questões que, entre outras, podemos colocar na conta de determinada visão de mundo que julga esses sujeitos inexistentes, ou indignos de história, fadados a viver nas sombras. Contudo, acreditamos que a atenção voltada para esses episódios de violência, seja física, seja pelo silêncio, são genuinamente necessários para a compreensão do fenômeno da contrarrevolução, bem como da própria noção de revolução e nação em Cuba além da visão estereotipada e propagada pelo regime historicamente.

\section{Os homossexuais na Revolução Cubana}

Não se pode dizer que a carência de trabalhos que abordem a questão da homossexualidade no tocante à contrarrevolução se deva à completa ausência de fontes quando o próprio Fidel se manifestou publicamente não apenas uma vez a respeito dos homossexuais. Em 1963, numa comemoração do sexto ano do assalto ao palácio presidencial, ocorrido em 1957, Fidel bradou em relação aos homossexuais:

Que no confundan la serenidad de la Revolución y la ecuanimidad de la Revolución con debilidades de la Revolución. Porque nuestra sociedad no 
puede darles cabida a esas degeneraciones. La sociedad socialista no puede permitir ese tipo de degeneraciones. ${ }^{4}$

Dois anos depois, numa entrevista a Lockwood, Fidel refletiu sobre a possibilidade de um homossexual ser um revolucionário:

Nada impede um homossexual de professar a ideologia revolucionária e, portanto, exibir uma postura política correta. No entanto, não temos como crer que um homossexual personifique as condições e condutas necessárias para possibilitar que o consideremos um verdadeiro revolucionário. Um desvio dessa natureza vai contra o conceito que temos de como um militante comunista deve ser (Citado em CHOMSKY, 2015, p. 185-186).

Vê-se, em ambas as declarações, que na visão do ditador o homossexual é um corpo estranho na revolução, uma debilidade, uma degeneração, um desvio da natureza. Na entrevista de 1965, Fidel justifica sua opinião com base numa suposta falta de "condições e condutas necessárias" que personificam um revolucionário. Quais condições seriam essas? Para além de professar a ideologia comunista oficial, o revolucionário tinha um perfil comportamental muito específico, baseado em concepções de gênero onde são definidas o papel do masculino e do feminino. O ícone da revolução, o guerrilheiro, materializado no próprio Fidel e em Che Guevara, era um símbolo de masculinidade que pautava condutas sociais sobre o papel do homem na sociedade, que todos deveriam seguí-lo, como demonstrou Rafael Saddi Teixeira (2009). Os homens que não incorporassem os traços associados ao masculino, como força, disposição para a guerra (para defender a pátria), virilidade e, supunha-se, a postura ativa no ato sexual, não eram considerados homens nem revolucionários, e sofriam uma série de violências físicas e simbólicas, como foram vítimas os afeminados e homossexuais.

${ }^{4}$ CASTRO, Fidel. Discurso pronunciado por El Comandante Fidel Castro Ruz, Primer Ministro del Gobierno Revolucionario de Cuba, en la clausura del acto para conmemorar el VI aniversario del Asalto al Palacio Presidencial, celebrado en la escalinata de la Universidad de La Habana, el 13 de Marzo de 1963. Disponível em: http://www.cuba.cu/gobierno/discursos/1963/esp/f130363e.html. Acesso em 18/05/2018. 
Além de discursos de Fidel Castro, outros foram produzidos a respeito do "ser revolucionário" que situava sua contrapartida diretamente na homossexualidade, como manifestações claramente homofóbicas de Che Guevara (MISKULIN, 2013, p. 142), o opúsculo publicado em 1963 pelo professor Gaspar Jorge García Galló, intitulado Nuestra Moral Socialista. Em todo o caso, postula-se a ideia de que a homossexualidade é incondizente com a revolução e os homossexuais devem ser isolados socialmente, corrigidos para se adaptarem ao padrão sexual da revolução, e assim, tal flagelo ser erradicado.

Como demonstrou Emílio Bejel (2006), a própria ideia de nação que existia em Cuba, desde o século XVIII, foi estruturada em torno de um modelo sexual masculino no qual os homossexuais são representados como páreas numa nação de heróis. Tal ideia permaneceu no tempo e se atualizou no contexto revolucionário, cujas emoções nacionalistas foram fortemente mobilizadas e associadas à defesa da revolução, para a qual os afeminados e homossexuais não eram qualificados, pelo que lhe faltavam de masculinidade. Como escreveu Tomás Robaina (2005), o homossexual impedia a constituição do corpo revolucionário ideal.

Durante toda a década de 1960 e 1970, vários acontecimentos indicaram a perseguição declarada aos homossexuais como autêntica medida revolucionária de glória nacional. Ainda em 1961, no dia 11 de outubro, a repressão pública aos homossexuais por parte do regime teve início com la noche dos tres $P$ (pederastas, prostitutas e proxenetas), quando a polícia prendeu prostitutas e prováveis homossexuais nas ruas de Havana Velha (MISKULIN, 2013, p. 141).

A perseguição aos homossexuais foi articulada entre a sociedade civil e militar, a partir da criação dos Comitês de Defesa Revolucionária (CDR), em 1960, que instituiu em cada bairro uma família representante do Comitê responsável por vigiar ações de sabotagem, auxiliar na campanha de alfabetização e, sobremaneira, descobrir focos de contrarrevolução que 
residia em determinadas posturas, como a vadiagem e a homossexualidade, uma de suas principais vítimas.

Muitos homossexuais foram enviados para campos de trabalho forçado, conhecidos como UMAPs (Unidades Militares de Ajuda à Produção), fase obscura da revolução, uma vez que até mesmo a data de seu funcionamento permanece incerta, devido a falta de fontes oficiais e também do deliberado esquecimento desse reduto dos considerados contrarrevolucionários pelo regime e lócus da barbárie. Alguns autores afirmam que elas teriam surgido na província de Camaguey por volta de 1965 e fechadas em 1967 ou 1968, devido protestos de intelectuais internacionais (YOUNG, 1985). Além de homossexuais, foram enviados para os campos jovens "antissociais", religiosos, aqueles que a dirigência considerou desafetos ideológicos que mereciam ser endireitados pelo trabalho sob vigilância militar (MASEDA, 2001). Detalhe: acreditava-se que a submissão de um homossexual ao trabalho braçal, que requer força física, e sob a presença de outros heterossexuais, convertê-lo-ia à normalidade heterossexual imprescindível num evolucionário. ${ }^{5}$

Antes da revolução, não havia uma política sistemática do Estado, calculada em termos ideológicos explícitos que classificavam os homossexuais como uma escória social. A partir de 1959, institucionalizouse em Cuba a política de aniquilação da homossexualidade. Evidentemente, o preconceito e o ódio aos homossexuais não surgiu com a revolução, mas sustentava-se na tradição de uma sociedade patriarcal, machista e homofóbica que, com o advento revolucionário, ganhou novos contornos inspirados na doutrina comunista que desde a União Soviética de Stálin via os homossexuais como um elemento decadente da sociedade burguesa, inadmissível, portanto, sob a revolução socialista. No combate ao capitalismo e às relações sociais burguesas (baluarte da contrarrevolução),

\footnotetext{
${ }^{5}$ Diz-se que, em 1967, haviam cerca de 60.000 homossexuais presos nas UMAPs. Após o fechamento dos campos sob protesto internacional, eles foram espalhados por todos os cárceres do país, e passaram então a possuir seções especiais no interior das prisões (BARRETO, 1996, p. 153-156)
} 
implicava suprimir a homossexualidade. A politização do ódio por parte da revolução foi incorporada na missão de construir o "homem novo", o sujeito utópico que viria a habitar a sociedade revolucionária. O "homem novo", entre outras características, era a completa negação de traços femininos, e representava a valorização de traços atribuídos ao masculino e essenciais num contexto de guerra no qual vivia Cuba: virilidade, força física, heterossexualidade, dedicação total à revolução e a seus preceitos morais e ideológicos. Era o modelo ideal do revolucionário para a sociedade que nascia, da qual os homossexuais não faziam parte em hipótese alguma. Ao contrário, por serem deslocados da masculinidade guerreira, e por não cumprirem a sexualidade convencional reforçada pelo regime, eram considerados fracos, passíveis de serem corrompidos pelo inimigo e que impediam a formação do "homem novo".

Como se vê, para que a revolução se consolidasse, era inadiável que a homossexualidade deixasse de existir em Cuba. O recrudescimento do regime, uma das bases de seu autoritarismo, perpassa justamente a estruturação da violência contra minorias sexuais. O autoritarismo do regime foi justificado pela segregação daqueles que não se adequavam à moral conservadora e à heterossexualidade compulsória que fundamentaram o imaginário da revolução. Se os homossexuais impediam a consumação do "homem novo", impediam a defesa da pátria, impediam a dignidade nacional, impediam a própria ideia de nação. Por isso que o ato de destruição dessas vidas encontrou grande legitimidade na sociedade que de diversas formas partilhou desses atos de barbárie.

O fechamento das UMAPs não significou o fim da violência. No $1^{\circ}$ Congresso Nacional de Educação e Cultura, ocorrido em abril de 1971, o comportamento dos cubanos foi normatizado nas resoluções do Congresso que definiu certas condutas como extravagantes, aberrações de indivíduos reconhecidamente antissociais contrários à "unidade ideológica" do povo cubano (RESOLUÇÕES, 1980, p. 21). Nesse congresso, a homossexualidade foi definida como "patologia social", considerada um "desvio" e que deveria 
ser erradicada, sob o risco de se alastrar pela sociedade, contaminar os jovens e bloquear o avanço da revolução. Por isso, os homossexuais deveriam ser isolados, endireitados e aqueles que tinham acesso à juventude por meio de veículos culturais, deveriam ser impedidos de ter suas ideias e obras publicadas. De modo que diversos intelectuais homossexuais foram parametrados pela revolução, silenciados e jogados ao ostracismo, quando qualquer produção crítica no interior da revolução, seja de um homossexual ou não, já era impedida pela doutrina ideológica (RESOLUÇÕES, 1980, p. 29). Mas tais medidas não eram restritas aos artistas e intelectuais, mas também todos os cubanos comuns, pois as resoluções diziam respeito à sociedade em geral e a homossexualidade era o alvo. Dois anos depois do Congresso, em 1973 foi promulgada a lei 1.249, que previa entre três a nove anos de prisão para quem "ostentasse" a homossexualidade, por ser um vício socialmente reprovável. A lei foi reformulada em 1979, acrescentando a possibilidade de multa aos acusados de ostentação da homossexualidade, além de reforçar o impedimento de publicação de qualquer material que viria a "perverter e degradar os costumes" (BARRETO, 1996, p. 164; 166167). Ostentar a homossexualidade, supõe-se, significa expressar trejeitos corporais que agridem a imagem que se tem do proceder másculo, rígido e agressivo que estruturam a noção de masculinidade revolucionária.

Um ano depois, no êxodo Mariel de 1980, quando aproximadamente 125.000 cubanos saíram da ilha pelo porto Mariel, insatisfeitos por diversos motivos com o regime de Fidel Castro, muitos homossexuais saíram de Cuba.$^{6}$ Contudo, não necessariamente por iniciativa própria, apesar de que seria compreensível caso o fosse, mas como indivíduos expulsos de seu país. Fidel aproveitou a abertura do porto para enviar para os Estados Unidos

\footnotetext{
${ }^{6}$ Nos primeiros dias de 1980 um chofer de ônibus invadiu a embaixada peruana em Havana para pedir asilo político. Os passageiros do ônibus o seguiram no ato. Em represália, Fidel mandou retirar a escolta da embaixada, mas devido a isso, em pouco tempo, para sua surpresa, dirigiram-se para a embaixada cerca de 10.000, do que se desdobrou uma das maiores crises humanitárias. Devido a repercussão do acontecimento, que durou meses, Fidel abriu as portas do porto Mariel. Esse episódio foi narrado por Reinaldo Arenas, escritor homossexual que fugiu de Cuba nesta ocasião, em sua autobiografia Antes que anoiteça (1995).
} 
toda sorte de indesejáveis que haviam em Cuba, como criminosos comuns, deficientes mentais, prostitutas e homossexuais, chamados pelo ditador de escória, dizendo que a revolução não precisava deles.

O imaginário revolucionário que se instituiu em Cuba é inseparável de suas políticas de segregação sexual. Os contrarrevolucionários não foram, portanto, apenas os dissidentes políticos, mas criou-se na engrenagem do regime uma arquitetura humana na qual o ideal revolucionário se nutria de critérios morais e sexuais muito específicos, dentro dos quais delineou-se um campo da contrarrevolução que retirava os direitos à vida, à liberdade e à justiça dos que não se enquadravam. De tal forma que os inimigos da revolução eram também aqueles historicamente oprimidos seja pela religião, seja pela moral burguesa hegemônica desde o século XIX, que foram inadmitidos no discurso de liberdade revolucionária, pois a Revolução Cubana não rompeu com tais preceitos morais e sexuais presentes no Ocidente. No imaginário da revolução, permeado de heróis nacionais, os dignos a habitarem a nação independente e a sociedade do futuro, baseado no "homem novo" másculo, viril, construiu sua contrapartida nos afeminados e homossexuais, sobre os quais perpetrou-se o terror.

O autoritarismo perpassa diversas vertentes ideológicas e se expressou de variadas formas durante o século XX, numa instigante capacidade de sedução. Para aqueles a que se voltam a repressão estatal e a supressão de direitos, suprime-se também o acesso à palavra, à existência, impõe-se o silêncio, o esquecimento. Na história da contrarrevolução, ainda persiste a ideia oficial de inimigos da pátria estrangeiros, divergentes ideológicos e políticos, quando outros sujeitos foram considerados contrarrevolucionários por sua forma de viver, de amar e usar o próprio corpo. Se quisermos compreender os processos políticos de nossa época, as diversas expressões ideológicas, devemos atinar para o quanto do Estado Moderno é fundamentado em preceitos morais que controlam a vida das pessoas e segregam, com base em normas provenientes da moral tradicional, diversas formas de alteridade, como foi o caso de Cuba. 
Publicações muito recentes sobre a história geral da Revolução Cubana, aqui no Brasil, ignoram esses episódios nada desprezíveis da construção da sociedade revolucionária, insistindo na narrativa de que a história cubana é uma história de luta pela independência desde o século XIX até os dias atuais, esquecendo as sombras que habitaram a revolução. A esse respeito, podemos lembrar, por exemplo, o livro de Alberto Moniz Bandeira (1998), De Martí a Fidel: A Revolução Cubana e a América Latina; outro seria o de Luis Fernando Ayerbe (2004), A Revolução Cubana, que faz parte de uma coletânea publicada pela Editora Unesp, sob direção de Emília Viotti, que aborda as revoluções do passado com uma finalidade bastante generosa, a saber, "servir de leitura complementar aos estudantes da escola média, universitários e ao público em geral” a fim de municiar os jovens insatisfeitos dos dias atuais na sua luta cotidiana pela transformação do mundo, "em busca de um futuro em que liberdade e igualdade sejam compatíveis, e a democracia seja a sua expressão". Recentemente foi publicado o livro da norte-americana Aviva Chomsky (2014), A história da Revolução Cubana, que possui um capítulo que trata da questão da sexualidade e a revolução, com uma atenção especial, mesmo que breve, para a perseguição aos homossexuais.

Caso queiramos um mundo democrático, igualitário, e que os movimentos políticos revolucionários, de mudança, não venham a repetir erros do passado, a historiografia deve dar seguimento à sua tarefa de dar voz aos esquecidos, aqueles cujas vidas foram apagadas nos escombros do tempo, em diversos lugares, sob diversas roupagens ideológicas. A história política, a história das revoluções, devem estar acompanhadas da compreensão da configuração cultural, que diz respeito aos comportamentos, à moral, à sexualidade, à raça, à diferença e à alteridade que compõem o quadro social onde as mudanças políticas acontecem. Tais questões não são menos importantes e fazem parte da própria esfera política. Há uma questão essencial que podemos dirigir à história da Revolução Cubana que não foge à regra, questão proposta por Joan Scott (1989, s/p) sobre os estudos de 
gênero, que as minorias sexuais, submetidas à desigualdade de gênero (mulheres, homossexuais, lésbicas, transexuais, travesti e outros) costumam ser as principais vítimas de regimes autoritários, porque as instituições políticas incorporam concepções de gênero e de dominação em seus pressupostos de organização. Nesse sentido, autores como Ayerbe (2004) e a chilena Marta Harnecker (2008) defendem a ideia de que as decisões centralistas do regime cubano e as medidas autoritárias foram inevitáveis diante do quadro de agressão externa e bloqueio econômico por parte dos EUA. Mas, pode-se perguntar, qual a relação dessa resposta política e geopolítica de defesa nacional, de dignidade da nação, com a tarefa interna paralela de erradicação da homossexualidade?

Tal ausência da discussão dessas questões na própria historiografia da revolução reflete também no ensino que ignora a problemática da sexualidade e sua relação com a configuração cultural e política da sociedade. A perseguição sistemática aos homossexuais como contrarrevolucionários permanece distante dos estudos gerais da revolução, e o preço que se paga é a compreensão limitada do fenômeno, a manutenção do silêncio e o enfraquecimento dos princípios democráticos. Há de se formar sujeitos críticos em relação a todos os aspectos da vida social, pois o silêncio sobre essas questões contribui para a perpetuação do preconceito, para a manutenção do ódio, para a submissão de indivíduos vilipendiados por noções morais e estruturas políticas que lhe negam a existência. A história não pode abrir mão de sua tarefa de lembrar o que os outros querem esquecer, como afirmou Eric Hobsbawm (1995) sobre o século XX, A Era dos extremos.

\section{Referências bibliográficas}

ARENAS, Reinaldo. Antes que anoiteça. Rio de Janeiro: Record, 1995. 
AYERBE, Luis Fernando. A Revolução Cubana. São Paulo: Editora UNESP, 2004.

ARBOLEYA, Jesus. La contrarrevolución cubana. Editorial de Ciencias Sociales. La Habana, 2000.

BANDEIRA, Alberto Moniz. De Martí a Fidel: a Revolução Cubana e a América Latina. Rio de Janeiro: Civilização Brasileira, 1998.

BARRETO, Teresa Cristófani. A libélula, a pitonisa. Revolução, homossexualismo e literatura em Virgílio Piñera. São Paulo: Iluminuras/Fapesp, 1996.

BEJEL, Emilio. Cuerpos peligrosos en una nación de héroes. La Habana: Revista Encuentro de la Cultura Cubana, 41/42, verano/otoño de 2006. p. 76-82 Disponível em:

https://www.cubaencuentro.com/revista/content/download/46034/399715/version/2/file 4142eb76.pdf. Acesso em: 18. mai. 2018.

CALEGARI, Ana Paula Cecon. Balanço sobre a historiografia para o estudo da "contrarrevolução cubana". Revista Eletrônica da ANPHLAC, n. 21, p. 125-148, Jul./Dez., 2016. p. 125-148.

CASTRO, Fidel. Palabras a los intelectuales. Havana, Ediciones del Consejo Nacional de Cultura, 1961.

CHOMSKY, Aviva. História da Revolução Cubana. São Paulo: Veneta, 2015.

FONT, Fabián Escalante. La Guerra Secreta: proyecto Cuba. La Habana: Editorial de Ciencias Sociales, 2008.

FIGAROLA, Joel James. Urgencias y exigencias historiográficas. Revista Temas: La Habana, n. 1, 1995.

FRANQUI, Carlos. Retrato de família com Fidel. Rio de. Janeiro: Record, 1981.

HARNECKER, Marta. Fidel: a estratégia política da vitória. São Paulo: Expressão Popular, 2008. 
HILB, Claudia. Silêncio, Cuba: a esquerda democrática diante do regime da Revolução Cubana. São Paulo: Paz e Terra, 2010.

HOBSBAWM, E. J. Era dos extremos: o breve século XX: 1914-1991. São Paulo: Companhia das Letras, 1995.

BOLENDER, Keith. Objetivo: voltear a Cuba. Una historia del terrorismo contra el gobierno de Fidel Castro. Buenos Aires: Capital Intelectual, 2011.

MASEDA, Hector. Los trabajos forzados en Cuba. Dossier El presídio Político en Cuba. Revista Encuentro de la cultura Cubana, p. 24-27, 2001. Disponível em: http://arch1.cubaencuentro.com/pdfs/20/20hm225.pdf. Acesso em: 18. mai. 2018.

MISKULIM, Sílvia Cesar. A política cultural no início da Revolução Cubana: o caso do suplemento cultural Lunes de Revolución. Revista Outubro, Edição 6, 2002. p. 77-90.

Os intelectuais cubanos e a política cultural da Revolução (1961-1975). São Paulo: Alameda, 2009.

. História, literatura e homossexualidade em Cuba: o caso de Virgílio Piñera. In.: COSTA, Adriane Vidal; BARBO, Daniel (orgs.). História, Literatura e Homossexualidade. Belo Horizonte: Fino Traço, 2013. p. 129-153.

RESOLUÇÕES do Primeiro Congresso Nacional de Educação e Cultura, São Paulo: Livramento, 1980.

ROBAINA, Tomás Fernández. Los homosexuales y la Revolución. La Habana: Revista Encuentro de la Cultura Cubana, 37/38, verano/otoño de 2005. Disponível em: https://www.cubaencuentro.com/revista/revista-encuentro/archivo/37-38verano-otono-de-2005/los-homosexuales-y-la-revolucion-28499. Acesso em: 18. mai. 2018.

TEIXEIRA, Rafael Saddi. O ascetismo revolucionário do Movimento 26 de Julho: o sacrifício e o corpo na Revolução Cubana (1952 a 1958). Tese (Doutorado) Universidade Federal de Goiás, Faculdade de História, Goiânia, 2009. 209 p. 
YOUNG, Allen. Los gays bajo la revolución cubana. Editor: Playor, 1984. 